\title{
Perancangan Aplikasi Komputer Berbasis Android untuk Survei Kondisi Kapal oleh Owner Surveyor
}

\author{
Paul Stevan Haloho dan Triwilaswandio Wuruk Pribadi \\ Jurusan Teknik Perkapalan, Fakultas Teknologi Kelautan, Institut Teknologi Sepuluh Nopember (ITS) \\ Jl. Arief Rahman Hakim, Surabaya 60111 Indonesia \\ e-mail: triwilas@na.its.ac.id
}

\begin{abstract}
Abstrak-Survei kondisi kapal adalah survei yang dilakukan oleh seorang Owner Surveyor untuk melaporkan kondisi aktual kapal beserta bagian-bagiannya. Proses survei yang dilakukan saat ini masih dilakukan secara manual dimana seorang Owner Surveyor melakukan survei berdasarkan daftar survei yang diterbitkan oleh perusahaan pemilik kapal. Hasil survei kondisi akan disajikan dalam bentuk laporan yang nantinya akan diserahkan kepada pemilik kapal sebagai bahan pertimbangan untuk dilakukannya "repair" dan "maintenance". Proses survei yang dilakukan saat ini tentu saja kurang efektif untuk dilakukan, mengingat tidak semua Owner Surveyor memiliki pengetahuan dan pengalaman yang sama serta proses pembuatan laporan hasil survei yang sering memakan waktu lama. Penelitian ini bertujuan untuk merancang sebuah aplikasi komputer berbasis android yang dapat membantu seorang Owner Surveyor dalam melakukan proses survei kondisi. Dalam aplikasi ini memuat fasilitas daftar survei, review survei, updating survei, dan menu untuk menambahkan Owner Surveyor. Aplikasi ini telah diujicobakan kepada beberapa responden yang memiliki pengalaman survei kapal dan pihak-pihak yang memiliki latar belakang pendidikan di bidang perkapalan. Pengujian ini dilakukan dalam bentuk kuisioner yang bertujuan untuk mengetahui penilaian para responden terhadap aplikasi ini. Dari hasil kuisioner dapat disimpulkan bahwa aplikasi ini sangat diperlukan dalam mendukung kegiatan survei kondisi kapal.
\end{abstract}

Kata Kunci- Aplikasi Komputer, Survei Kondisi Kapal, Owner Surveyor, Aplikasi Android Survei Kondisi Kapal.

\section{PENDAHULUAN}

$\mathrm{K}$ APAL sebagai transportasi laut akan mengalami kerusakan baik pada hull, konstruksi maupun peralatanperalatan yang ada pada kapal yang disebabkan oleh operasi kapal, dampak lingkungan maupun kecelakaan yang terjadi. Oleh karena itu, untuk menstabilkan kondisi kapal agar tetap optimal dibutuhkan proses pengecekan berkala atau biasa disebut survei kondisi kapal. Survei ini dilakukan guna mengetahui kondisi aktual kapal, biaya untuk memenuhi pencapaian standar, masa depan biaya pemeliharaan yang direncanakan selama periode yang dipilih, serta rekomendasirekomendasi terkait. Setelah data tersebut diperoleh, pihak pemilik ataupun yang terkait akan melakukan studi kelayakan dalam pengambilan keputusan untuk dilakukannya reparasi atau perbaikan.

Proses survei ini dilakukan oleh Owner Surveyor atau pihak terkait. Dalam melakukan proses survei dibutuhkan Owner Surveyor yang berpengalaman dan memiliki pengetahuan yang memadai. Hasil survei kondisi ini akan dikemas dalam bentuk laporan yang tentu saja akan memakan waktu yang relatif lebih lama.

\section{STUDI PUSTAKA}

\section{A. Survei Kondisi Kapal}

Dalam bidang perkapalan perawatan kapal perlu dilakukan untuk mempertahankan ketahanan kapal agar life time nya lama sehingga tingkat produktivitas berjalan lancar serta tidak terganggu akibat adanya kerusakan kapal [1]. Selain itu juga dilakukan survei secara berkala untuk pengecekan kondisi kapal sekaligus pendataan kapal pada Class. Tujuan perawatan kapal adalah menjamin terlaksananya pelaksanaan sistem pemeliharaan terencana (PMS, Planned Maintenance System) di kapal yang memenuhi persyaratan sesuai dengan [2]:

1. Peraturan Pemerintah (Statutories) yang mengacu ke Konvensi IMO (International Maritime Organization); yaitu: Safety of Life at Sea (SOLAS) \& Marine Pollution (MARPOL)

2. Peraturan Class baik itu BKI, LR, GL dan Lain-lain

3. Buku Petunjuk Pemeliharaan dari Manufacturer.

B. Manfaat Survei Kondisi Kapal

Survei kondisi mempunyai beberapa manfaat, antara lain [3]:

1. Mengetahui kondisi kapal aktual.

Survei ini dilakukan untuk mengetahui kondisi terkini dari suatu kapal.

2. Mengetahui potensi renovasi.

Setelah mengetahui kondisi dari suatu kapal, maka dapat diperkirakan bagian-bagian yang memerlukan maintanance dan repair.

3. Perkiraan biaya repair/ maintenance secara lebih spesifik.

Setelah ditentukan bagian-bagian yang akan diganti, maka tahapan selanjutnya dapat mengestimasi jumlah biaya yang akan dikeluarkan serta menghitung kelayakan penggantian dan investasi ini.

4. Kejelasan dokumen.

Survei kondisi juga sebagai alasan untuk melakukan updating terhadap dokumen-dokumen kapal. 


\section{Komponen Dalam Survei Kondisi Kapal}

Didalam sebuah laporan survei kondisi Raets Marine Insurance B.V telah dijelaskan beberapa aspek atau komponen didalam kapal yang harus dilakukan pemeriksaan pada saat survei kondisi. Komponen-komponen tersebut adalah sebagai berikut:

1. Certifications and documents

2. Hull and deck arrangements

3. Machinery and Electrical

4. Outfitting

5. Navigations and Safety Equpiments

\section{Owner Surveyor}

Seorang Owner Surveyor menyiapkan laporan untuk pemilik kapal yang akan menilai dua hal:

1. Kondisi kapal secara umum.

2. Cara-cara untuk memperkecil risiko yang ada.

Survei yang baik tidaklah terbatas pada kondisi-kondisi fisik saja, meskipun hal ini merupakan aspek yang sangat penting. Awak kapal, praktek-praktek kegiatan kerja/ operasional dari perusahaan dan tindakan-tindakannya dalam menangani masalah keselamatan juga harus diperhatikan (kalau perlu didemonstrasikan) dan dinilai. Sebagai contoh, Owner Surveyor akan menetapkan apakah awak kapal telah menjalani pelatihan yang benar/ tepat dan berpengalaman dalam mengoperasikan kapal dalam tujuan pelayarannya. Secara keseluruhan, Owner Surveyor akan mempertimbangkan apakah awak kapal memiliki keterampilan-keterampilan yang diperlukan untuk menyelesaikan kegiatan operasi kapal tanpa membahayakan kapal, mencederai diri mereka sendiri atau orang lain, atau merusak bangunan- bangunan lainnya seperti dermaga pelabuhan, anjungan lepas pantai dan lain sebagainya.

Owner Surveyor juga bisa diharapkan untuk menentukan apakah pemilik/ pengelola kapal memberikan perhatian atau menganggarkan/ menginventasikan masalah-masalah keselamatan dan pelatihan, menjaga dan merawat peralatan mekanis kapal dengan baik, dan indikator-indikator lainnya yang menunjukkan praktek-praktek kerja yang benar/sehat (sound business practices). Perusahaan pelayaran yang hanya memberikan perhatian yang kecil pada hal-hal di atas, dari sudut pandang lain perusahaan asuransi, bisa dianggap sebagai tidak peduli dengan hal-hal lain yang menyebabkan kapalnya berisiko tinggi.

\section{E. Aplikasi Komputer Berbasis Android}

Android adalah Operating System untuk alat komunikasi seperti ponsel pintar dan komputer tablet. Dikembangkan oleh Open Handset Alliance dipimpin oleh Google. Android menggunakan mesin virtual Dalvik hanya dalam penyusunan waktu untuk menjalankan dikompilasi kode Java. Android memiliki komunitas pengembang yang besar membuat aplikasi "apps" yang memperluas fungsionalitas dari perangkat [4]. Pada awalnya sistem operasi ini dikembangkan oleh Android Inc. yang kemudian dibeli oleh Google pada tahun 2005.

\section{METODOLOGI PENELITIAN}

\section{A. Studi Literatur dan Studi Lapangan}

Studi literatur adalah studi teori-teori yang akan digunakan dalam menyelesaikan tugas akhir serta untuk lebih memahami permasalahan yang akan dibahas dalam tugas akhir ini. Referensi-referensi untuk mengerjakan tugas akhir ini didapat dari buku, jurnal ilmiah, paper, tugas akhir sebelumnya yang masih berkaitan, serta browsing dari internet yang kompeten dan dapat dipertanggungjawabkan. Selanjutnya yaitu melakukan studi lapangan apakah teori yang didapatkan memiliki relevansi sehingga kedua metode studi ini dapat mengarah pada sinkronisasi berupa problem solving. Dasar teori yang menjadi fokusan untuk ditelaah antara lain :

- Dasar teori pemahaman secara umum tentang kapal dan awaknya.

- Dasar teori pemahaman survei kondisi kapal.

- Mekanisme merancang program aplikasi komputer menggunakan bahasa pemrograman yang sederhana untuk dipelajari.

- Implementasi panduan survei kondisi ke dalam program aplikasi.

\section{B. Pengumpulan Data}

Pengumpulan data disini merupakan data-data yang dijadikan dasar untuk melakukan proses perancangan aplikasi berbasis komputer. Data-data yang dibutuhkan untuk pengerjaan tugas akhir ini yaitu;

- Data mengenai metode survei kondisi kapal yang dilakukan oleh Owner Surveyor. Data berupa prosedur servei, item-item survei, dan metode penyajian laporan hasil survei. Dalam penelitian ini beberapa keterangan data didapatkan berdasarkan wawancara pada seorang expert.

- Data kategori kapal dan spesifikasi tekniknya sesuai dengan batasan yang telah ditentukan

- Data mekanisme perancangan aplikasi komputer berbasis android.

Data perihal aplikasi komputer berbasis yang dapat memberikan representasi bahwa proses survei kondisi kapal dapat dilakukan lebih mudah melalui aplikasi yang akan dibuat. Data-data tersebut diperoleh dari beberapa literatur atau referensi yang ada di internet, text book, artikel, jurnal, diktat serta judgement ekspertis dan lain sebagainya.

\section{Pengolahan Data}

Tahap pengolahan data dilakukan setelah data-data dari berbagai sumber referensi telah terkumpul. Berdasarkan batasan yang telah ditentukan, berikut mekanisme analisa dan pengolahan data dalam penelitian ini:

- Pengelompokkan bagian kapal untuk dijadikan bahan dalam merancangan sistem manajemen data pada aplikasi yang akan dirancang.

- Pembuatan kalimat panduan survei kondisi yang mudah dipahami. Panduan survei ini akan disajikan pada aplikasi yang akan dibuat dan dapat di akses Owner Surveyor sebagai userketika melakukan survei kondisi.

- Pembuatan template survei kondisi berdasarkan hasil 
pengelompokkan bagian kapal.

- Pembuatan moke up aplikasi android.

\section{Perancangan Program Aplikasi Android}

Aplikasi android dirancang dengan menggunakan program sublime text 2 yang merupakan program text editor untuk menulis bahasa pemograman. Dalam perancangan database, penulis menggunakan aplikasi database PostgreSQL dengan hosting di server dengan alamat yang dapat diakses yang didalamnya terdapat fasilitas PHPPGadmin.

\section{SURVEI KONDISI KAPAL}

\section{A. Sistem Survei Kondisi Kapal Saat Ini}

Dalam melakukan survei kondisi kapal, dapat dilakukan ketika kapal beroperasi atau pada saat kapal berlabuh. Hal ini bergantung pada kebijakan yang dikeluarkan oleh kantor pusat. Biasanya seorang Owner Surveyor bertanggung jawab tidak hanya kepada satu kapal melainkan beberapa kapal. Dalam melakukan pemeriksaan, seorang Owner Surveyor akan membawa survey list yang dikeluarkan oleh kantor pusat. Survey list ini berisi komponen-komponen kapal yang akan di survei dan disajikan dalam bentuk checklist. Seorang Owner Surveyor akan melakukan pengisian survey list berdasarkan apa yang ditemukan di lapangan dan melakukan dokumentasi berupa foto. Pengisian dilakukan secara tulis tangan manual oleh Owner Surveyor dengan melengkapi checklist yang ada dan dapat dilakukan pengisian catatan tambahan apabila diperlukan.

Pemeriksaan yang dilakukan seorang Owner Surveyor terintegrasi dengan awak kapal.seperti Kapten, Kepala Kamar Mesin, Mualim I, dst. Owner Surveyor akan menerima laporan dari awak kapal mengenai kerusakan-kerusakan yang ada, dan meninjau secara langsung. Hal ini bertujuan agar proses survei dapat berjalan lebih singkat, sehingga laporan hasil survei dapat segera dikemas dan disampaikan kepada pihak pemilik kapal atau pihak terkait dan segera dilakukan pengambilan keputusan untuk dilakukannya repair atau maintenance oleh pemilik kapal atau pihak terkait.

Dalam melakukan penyajian laporan hasil survei, survey list yang telah dilengkapi oleh Owner Surveyor akan di rekap pada komputer. Laporan survei yang dibuat akan dilengkapi keterangan dan foto sebagai bukti pendukung kondisi aktual di lapangan. Laporan hasil survei yang sudah disampaikan kepada pihak pemilik kapal atau pihak lain terkait, akan direkap sebagai acuan bahan pertimbangan untuk dilakukannya perawatan kapal sebagai bentuk Planning Maintenance System.

\section{B. Survey List}

Survey list dikeluarkan perusahaan pemilik kapal sebagai acuan untuk seorang Owner Surveyor melakukan survei kondisi di lapangan. Form ini menampilkan daftar bagianbagian dari kapal yang hendak dilakukan pemeriksaan seperti yang ditampilkan pada Tabel 1 yang merupakan salah satu contoh survey list dari PT. Dharma Lautan Utama. Dapat dilihat dari Tabel 1 terdapat juga checklist dan kolom untuk keterangan tambahan yang dapat diisi oleh Owner Surveyor.

Tabel 1. Contoh survey list kondisi kapal PT. Dharma Lautan Utama

\begin{tabular}{|c|c|c|c|c|}
\hline \multicolumn{2}{|c|}{ Sistem } & \multicolumn{2}{|c|}{ Kondisi } & \multirow[t]{2}{*}{ Keterangan } \\
\hline Sistem Utama & Sub-Sistem & Ok & $\mathbf{x}$ & \\
\hline \multirow{10}{*}{$\begin{array}{l}\text { ANJUNGAN \& TOP } \\
\text { DECK }\end{array}$} & Sistem Kemudi & & & \\
\hline & Sistem Alat Nav. & & & \\
\hline & Sistem Komunikasi & & & \\
\hline & Alat Keselamatan & & & \\
\hline & $\begin{array}{l}\text { Kelistrikan \& Control } \\
\text { Panel }\end{array}$ & & & \\
\hline & $\begin{array}{l}\text { Peralatan \& } \\
\text { Kelengkapan lain }\end{array}$ & & & \\
\hline & Interior & & & \\
\hline & Kostruksi \& Perpipaan & & & \\
\hline & Permesinan & & & \\
\hline & Fasilitas Penumpang & & & \\
\hline $\begin{array}{l}\text { FASILITAS LAYANAN } \\
\text { JASA }\end{array}$ & Ruang Informasi & & & \\
\hline
\end{tabular}

\section{Bentuk Laporan Survei}

Bentuk laporan yang disajikan dalam sistem tersebut adalah print out dari laporan yang diketik secara langsung berdasarkan data yang diperoleh dari survey list ketika Owner Surveyor melakukan survei kondisi. Bentuk laporan survei dapat dilihat pada Gambar 1 berikut.

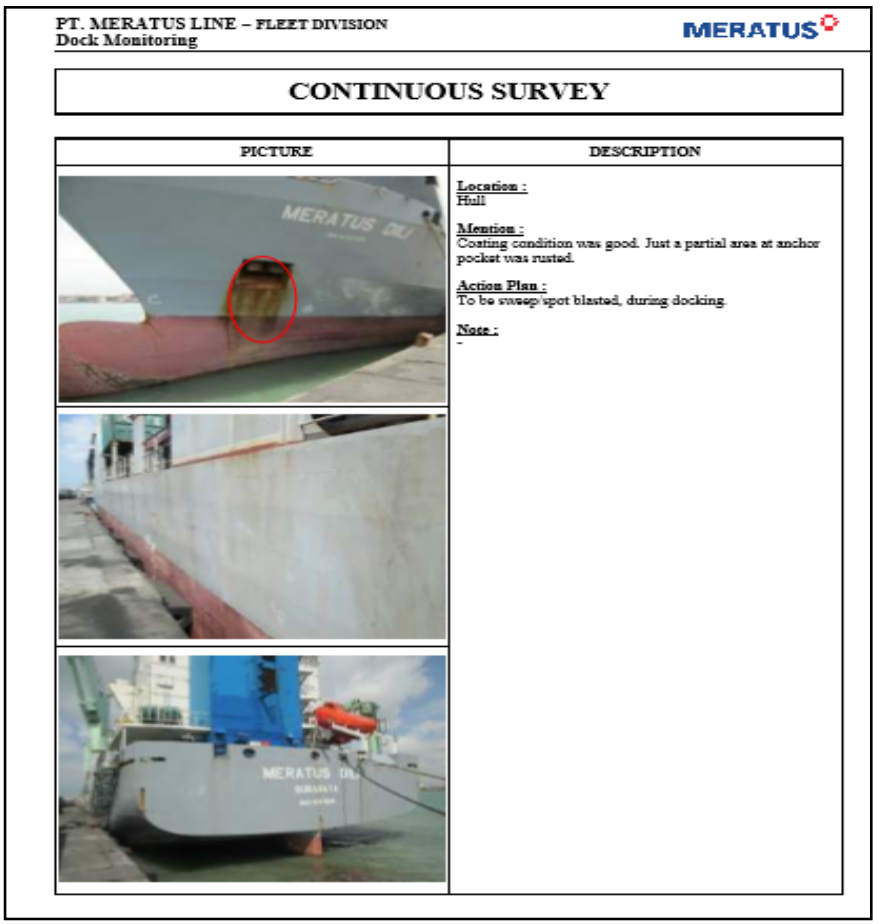

Gambar 1. Contoh laporan hasil survei kondisi kapal PT. Meratus Line

Penyajian laporan survei kondisi seperti Gambar 1 diatas dilakukan secara manual tanpa adanya sistem komputerisasi. Adapun bentuk laporan survei kondisi terdiri dari:

1. Laporan Pengawasan

Laporan yang berisi segala sesuatu pada bagian kapal yang diperiksa. Laporan ini merupakan laporan hasil rekapan dari list survei yang telah dilengkapi Owner Surveyor ketika melakukan survei kondisi kapal.

2. Dokumentasi

Dalam upaya melengkapi data dan informasi survei kondisi, seorang Owner Surveyor menggunakan foto hasil dokumentasi yang didapatkan ketika melakukan proses survei kondisi. 


\section{Kelemahan Survei Kondisi Saat Ini}

Proses survei kondisi yang dilakukan saat ini dilakukan secara manual dengan lembaran survey list yang diisi oleh Owner Surveyor ketika melakukan survei kondisi kapal. Survey list yang ada akan diolah secara manual dengan pengetikan manual ke laptop atau $p c$ dan disajikan dalam bentuk laporan yang disertai gambar dokumentasi. Hal ini tentu saja kurang efektif dikarenakan membutuhkan waktu yang cukup lama. Sehingga diperlukan adanya suatu metode baru yang dapat membantu proses survei kondisi kapal oleh Owner Surveyor.

\section{PERANCANGAN PROGRAM APLIKASI}

\section{A. Penjelasan Umum Program Aplikasi}

Aplikasi ini menyajikan dua fungsi $\log$ in, dimana $\log$ in yang pertama ditujukan kepada Administrator. Fungsi log in Administrator ditujukan kepada perwakilan pihak perusahaan pemilik kapal yang memiliki wewenang untuk melakukan editing parameter survei dan mengakses laporan survei. Fungsi $\log$ in yang kedua ditujukan kepada User. User merupakan seorang Owner Surveyor yang hendak melakukan survei kondisi. User dapat memanfaatkan aplikasi ini untuk melakukan survei kondisi kapal. Pengisian form survei yang disajikan pada aplikasi ini akan dilengkapi oleh User sesuai dengan fakta yang ada dilapangan. Hasil survei akan simpan ke server sehingga laporan dapat segera diakses oleh Administrator selaku pihak perwakilan perusahaan pemilik kapal.

\section{B. Penyusunan Database}

Dalam perancangan database, penulis menggunakan aplikasi database PostgreSQL dengan hosting di server dengan alamat yang dapat diakses yang didalamnya terdapat fasilitas PHPPGadmin. Untuk mengakses database, ada beberapa langkah yang harus dilakukan, sebagai berikut :

1. Akses alamat melalui web browser (Mozilla Firefox atau Google Chrome). Kemudian log in seperti yang ditampilkan pada Gambar 2 berikut.

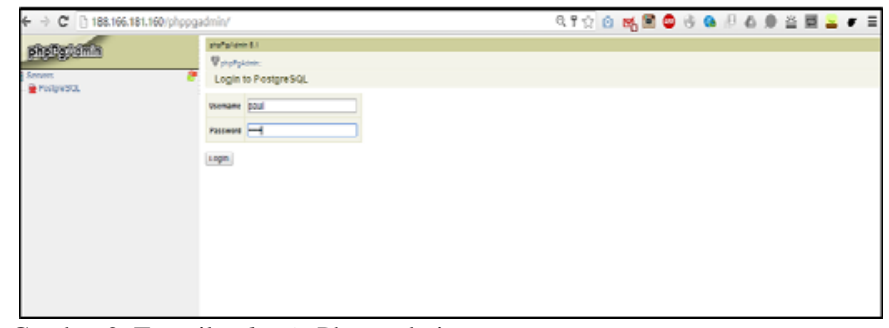

Gambar 2. Tampilan log in Phppgadmin

2. Untuk membuat database yang baru, maka harus create new database. Setiap database akan tersusun dari tabeltabel. Setiap tabel didalam database menggambarkan entitasnya. Setiap tabel tersusun dari berbagai attribute dari entitas. Setiap tabel juga terdapat satu attribute sebagai primary key dan foreign key . Primary key adalah suatu elemen record yang dipakai untuk menemukan record tersebut pada waktu diakses atau digunakan untuk identifikasi tiap record, Sedangkan Foreign key adalah suatu elemen record yang menunjukkan hubungan antara entitas satu dengan yang lainnya [5]. Proses pembuatan database baru dapat dilihat pada Gambar 3 berikut.

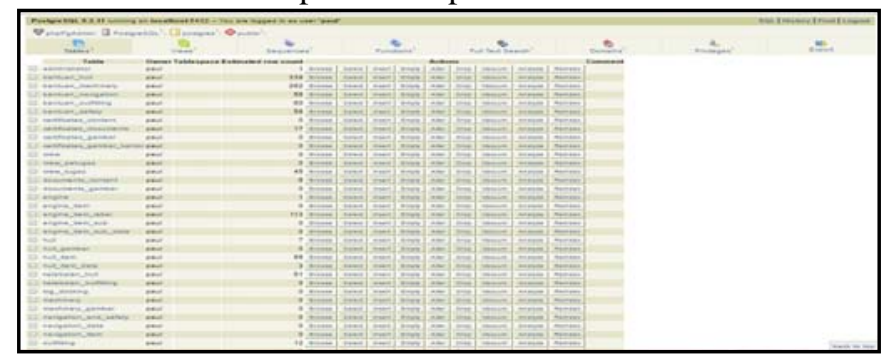

Gambar 3.Daftar Tabel/entitas dalam database postgreSQL

\section{Simulasi Aplikasi}

Adapun simulasi tampilan aplikasi komputer berbasis android untuk survei kondisi kapal adalah sebagai berikut;

\section{1) Administrator}

Administrator adalah super User disini. Administrator memiliki otoritas penuh pada program ini, dimana Administrator dapat mengisi data informasi untuk persiapan survei dan juga fungsi edit. Administrator juga mampu melihat serta mengubah laporan hasil survei. Daftar otoritas Administrator;

- Mengisi dan merubah identitas kapal.

- Mengisi dan dapat menggunakan fungsi edit dalam pengisian database.

- Dapat melihat dan merubah laporan hasil database.

- Melihat detail profil Owner Surveyor.

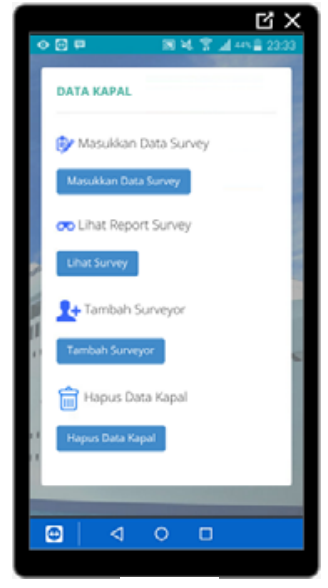

(a)

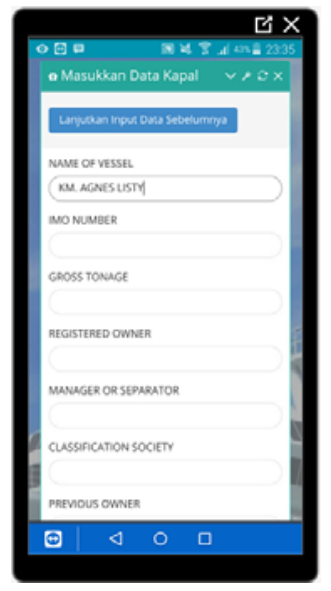

(b)
Gambar 4.(a) Fasilitas menu pilihan pada aplikasi dan (b) Proses pengisian data kapal

Gambar 4(a) merupakan tampilan dari menu utama setelah Administrator melakukan log in. Pada halaman menu akan ditampilkan beberapa pilihan untuk Administrator dalam menjalankan aplikasi android. Pada kondisi ini penulis akan memilih menu masukkan data survei sehingga akan ditampilkan form pengisian data kapal seperti Gambar 4(b) diatas. Data kapal yang diisi oleh Administrator akan tersimpan pada server dan dapat di akses untuk ditampilkan pada aplikasi yang akan digunaka User. Hal ini bertujuan untuk mempermudah User dalam memilih dan menampilkan 
data kapal yang hendak di survei tanpa harus dilakukannya pendataan dari awal oleh User.

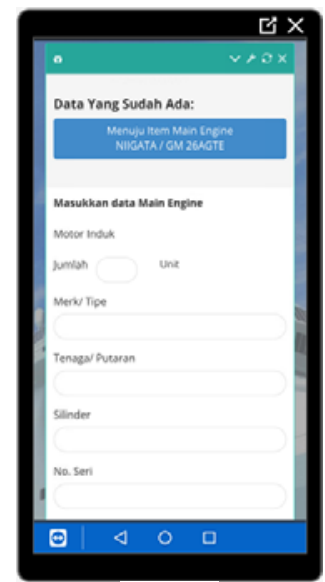

(a)

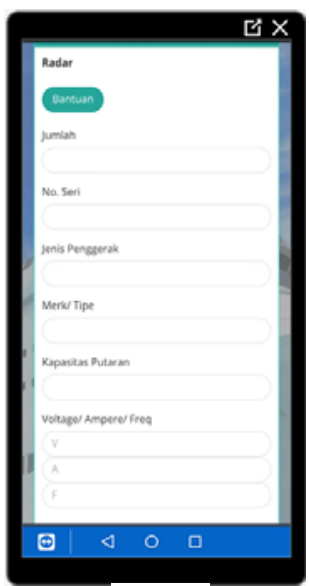

(b)
Gambar 5.(a) Form data main engine dan (b) Form data Radar

Gambar 5(a) merupakan form pengisian data main engine kapal. Data main engine yang telah diisi akan tersimpan dan dapat diakses oleh User ketika melakukan survei di lapangan. Gambar 5(b) merupakan form pengisian data radar kapal yang fungsinya serupa dengan sebelumnya.

2) User

Surveyor mempunyai otoritas sebagai User untuk mengisi form data yang telah tersedia. Form tersebut diisi berdasarkan pengamatan langsung dilapangan, selain itu User ini memberikan komentar terkait poin-poin yang ada didalam form. User juga dapat melakukan view survey report dan melakukan updating survey. Daftar otoritas Surveyor;

- Mengisi form yang telah disediakan program.

- Mengubah isi di dalam form.

- Memberikan komentar terkait poin-poin didalam form.

- Mengakses survey report sebelumnya.

- Melakukan updating survey.

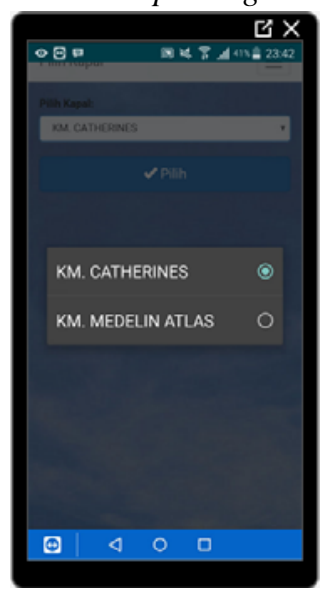

(a)

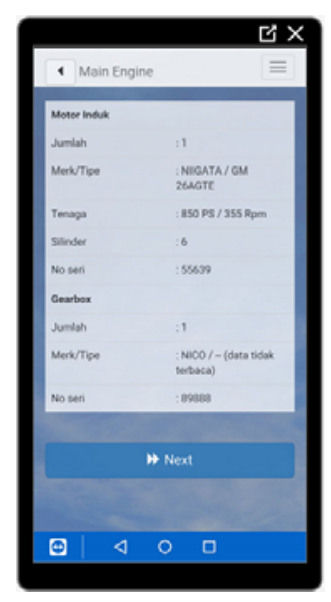

(b)
Gambar 6.(a) Pemilihan kapal dan (b) Informasi data main engine

Gambar 6(a) merupakan proses dari pemilihan kapal yang dilakukan oleh User setelah melakukan fungsi log in. Setelah melakukan pemilihan kapal maka dapat dilakukan pemilihan bagian kapal yang hendak di survei. Pada kondisi ini penulis akan memilih main engine sehingga akan ditampilkan data informasi main engine seperti Gambar 6(b).

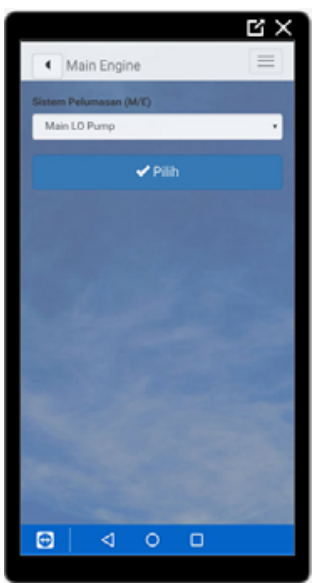

(a)

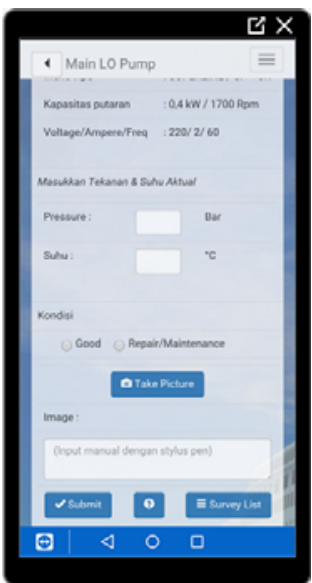

(b)
Gambar 7.(a) Pemilihan main L.O pump dan (b) Form survei main L.O pump

Gambar 7(a) merupakan proses pemilihan main L.O pump yang merupakan bagian dari main engine. Setelah dilakukannya pemilihan terhadap main L.0 pump maka akan ditampilkan form survei seperti Gambar 7(b).

\section{ANALISA SISTEM DAN UJI COBA APLIKASI}

\section{A. Analisa Sistem}

Setelah dijelaskan pada sub bab sebelumnya, maka dapat dilihat hasil perbandingan sistem pada Tabel 2 dibawah ini.

Tabel 2. Analisa perbandingan sistem

\begin{tabular}{|c|l|c|c|c|c|c|c|}
\hline \multirow{2}{*}{ No } & \multicolumn{1}{|c|}{ Analisa Kegiatan } & \multicolumn{2}{|c|}{ Waktu } & \multicolumn{2}{c|}{ Tempat } & \multicolumn{2}{c|}{ Keterangan } \\
\cline { 3 - 9 } & & Manual & Aplikasi & Manual & Aplikasi & Manual & Aplikasi \\
\hline 1 & Penyusunan Laporan Survei & 1 hari & 30 menit & & & & \\
\hline 2 & Penyampaian Laporan & 1 hari & 1 menit & & & & \\
\hline 3 & Review Laporan Survei & 5 menit & 10 detik & & & & \\
\hline 4 & Penyimpanan Laporan Survei & & & Lemari & Server & & \\
\hline 5 & Pemerikasaan Kondisi Kapal & & & & & Terencana & Terencana \& Detail \\
\hline 6 & Pengambilan keputusan & & & & & Kurang Cepat & Cepat \& Sesuai \\
\hline
\end{tabular}

Dari Tabel 2 diatas, dapat dilihat perbandingan sistem antara sistem yang digunakan sekarang dengan sistem yang menggunakan program ini. Dapat dilihat bahwa perbedaan untuk waktu dan tempat penyimpanan hasil laporan survei kondisi keduanya sangat signifikan. Proses yang dilakukan secara manual membutuhkan waktu yang cukup lama dalam penyusunan laporan survei yaitu satu hari, sedangkan dengan aplikasi ini hanya membutuhkan waktu 30 menit. Hal ini dikarenakan penyusunan laporan dilakukan secara otomatis oleh sistem, bukan dilakukan secara manual dengan pengetikan menggunakan media $p c$. Media penyimpanan yang digunakan adalah server sehingga lebih praktis digunakan. User dan Administrator dapat mengirim dan mengakses data kapanpun dan dimanapun. Hal ini tentu jauh lebih efektif dibandingkan dengan penggunaan lemari berkas.

\section{B. Uji Coba Aplikasi}

Untuk menganalisa kelayakan, program diaplikasikan ke 
pada pihak-pihak yang memiliki pengalaman survei kapal dan pihak-pihak yang memiliki latarbelakang pendidikan di bidang perkapalan. Pengujian ini dalam bentuk kuisioner untuk mengetahui respon pihak-pihak yang nantinya terkait apabila program ini diaplikasikan seperti Gambar 8 dibawah.

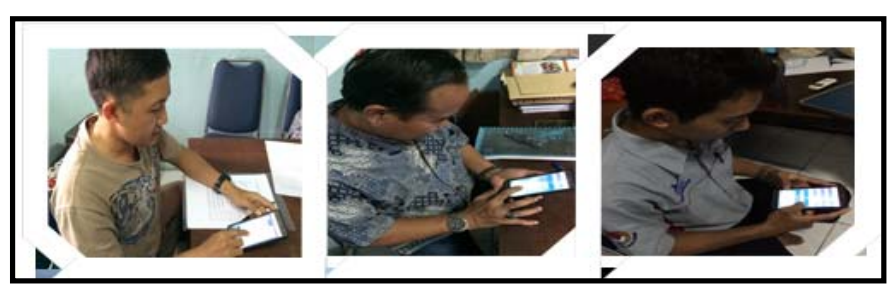

Gambar 8. Pengujian aplikasi oleh responden

\section{KESIMPULAN/RINGKASAN}

\section{A. Kesimpulan}

1. Sistem survei kondisi kapal yang ada saat ini masih dilakukan secara manual oleh Owner Surveyor menggunakan daftar survei yang dikeluarkan perusahaan pemilik kapal. Dalam melakukan penyajian laporan hasil survei, daftar survei yang telah dilengkapi oleh Owner Surveyor akan di rekap pada komputer.

2. Dalam merancang sistem survei kondisi yang baru, telah dilakukan survei kondisi kapal menggunakan prosedur survei yang ada dan ditentukannya parameterparameter yang akan diimplementasikan dalam bentuk aplikasi android. Terdapat dua aplikasi yang akan dirancang yaitu aplikasi untuk Administrator dan aplikasi untuk User. Daftar otoritas dalam menu aplikasi Administrator terdiri dari (1) Mengisi dan merubah identitas kapal (2) Mengisi dan dapat menggunakan fungsi edit dalam pengisian database (3) Dapat melihat dan merubah laporan hasil database (4) Melihat detail profil Owner Surveyor. Daftar otoritas dalam menu aplikasi User terdiri dari (1) Mengisi form yang telah disediakan program (2) Mengubah isi di dalam form (3) Memberikan komentar terkait poinpoin didalam form (4) Mengakses survey report sebelumnya (5) Melakukan updating survey.

3. Sistem survei kondisi yang baru dapat diimplementasikan dalam bentuk aplikasi komputer berbasis android. Aplikasi ini memiliki kelebihan dalam melakukan penyajian laporan secara otomatis ketika User telah melakukan pengisian form survei ketika melakukan survei di lapangan. Aplikasi ini telah diujicobakan kepada beberapa responden yang memiliki pengalaman survei kapal dan pihak-pihak yang memiliki latar belakang pendidikan di bidang perkapalan. Pengujian ini dilakukan dalam bentuk running aplikasi oleh beberapa responden dilanjutkan dengan pengisian kuisioner yang bertujuan untuk mengetahui penilaian para responden terhadap aplikasi ini. Dari hasil kuisioner dapat disimpulkan bahwa aplikasi ini sangat diperlukan dalam mendukung kegiatan survei kondisi kapal.

\section{UCAPAN TERIMA KASIH}

Penulis mengucapkan terima kasih kepada Ayah dan Ibu tercinta yang telah membesarkan penulis atas do'a, kasih sayang, dukungan, dan bimbingannya yang tidak pernah berhenti

Penulis mengucapkan terima kasih kepada Bapak Ir. Triwilaswandio Wuruk Pribadi, M.Sc. selaku dosen pembimbing yang telah membimbing penelitian ini sampai terbitnya jurnal ini.

\section{DAFTAR PUSTAKA}

[1] Soejitno. 1997. Teknik Reparasi Kapal dan Teknik Produksi. Surabaya: Fakultas Teknologi Kelautan - ITS.

[2] Daji, Adjie. 2012. Manajemen Perawatan Kapal. http://adjiedaji.blogspot.co.id/2012/08/manajemen-perawatankapal.html. Diakses pada 5 Oktober 2015.

[3] Prasetya, Hendy. 2014. Perancangan Model Survei Kondisi Kapal Bekas Berbasis Online. Skripsi. Tidak dipublikasikan. Surabaya: Jurusan Teknik Perkapalan FTK/ITS.

[4] Manjunath. 2013. Membuat Aplikasi Android dengan Cordova. Jakarta: Gramedia.

[5] Nugroho, Bunafit. 2004. PHP dan MySQL dengan Editor Dreamweaver $M X$. Yogyakarta: Andi. 